\title{
A TALE OF TWO IMPERIAL RESIDENCES: AURANGZEB'S ARCHITECTURAL PATRONAGE
}

| Received June 20th 2016 | Accepted July 19th 2016 | Available online December 20th 2016 |

DOI http://dx.doi.org/10.18860/jia.v4i2.3514 |

\section{Pushkar Sohoni}

Department of Architecture,

University of Pennsylvania,

United States

psohoni@gmail.com

\begin{abstract}
While the Mughal Emperor Aurangzeb Alamgir is not well-known for his architectural commissions as his predecessors, there are still a few extant buildings associated with him. Two of these are residential sites, built almost fifty years apart, at the beginning and end of his reign as an emperor. This essay examines these hitherto unpublished sites, and documents them as part of a Mughal legacy in the Deccan that has remained uncelebrated. The palace at Aurangabad and a royal residential compound just outside of Ahmadnagar are the two sites which mark the beginning and the end of the emperor's reign and offer an insight into his political fortunes and religious life as it changed.
\end{abstract}

KEYWORDS: Mughal architecture, Deccan, Aurangabad, Ahmadnagar, Aurangzeb

\section{INTRODUCTION}

The Mughal emperor Aurangzeb Alamgir (16181707; reg. 1658-1707) was an enigmatic personality in the history of South Asia. Aurangzeb assumed the name of Alamgir only on becoming the Emperor in 1658. For this paper, the name Aurangzeb has been used throughout this essay, the name Alamgir being used only for the eponymous site near Ahmadnagar. Unlike the Mughal emperors who preceded him, he is not directly credited with a lot of architectural activity other than religious and pious buildings. For example, Aurangzeb's personality and architectural contributions are described thus: "Awrangzib was known for his piety and zeal, and his reign was marked by a gradual increase in Islamic orthodoxy. The latter part of his reign marks the end of a great age of imperial Mughal patronage. Awrangzib added little to the imperial palaces built by his forebears but commissioned the construction of a number of mosques" [1]. Aurangzeb is credited with commissioning the Badshahi Mosque in Lahore (1671), and was also responsible for various mosque expansions such as the Jami' Mosque in Bijapur (1686) and the Mecca Mosque in Hyderabad (1687). The construction and enlargement of mosques is often understood as an expression of his Sunni zeal. In the Deccan, where he spent much of his life, first as the Viceroy (ca. 1636-45, 1653-58) and later as the Mughal Emperor (ca. 1683-1707), only two sites other than mosques are popularly associated with him, both funerary: the Bibi-ka-Maqbara mausoleum that he built for his wife in Aurangabad, and his own grave at Khuldabad. Both are well-known, and serve to highlight his complex personality. The ostentatious Bibi-kaMaqbara (literally 'Tomb of the Queen' in Urdu) was built in memory of his wife Rabi'a Durrani (d. 1657), a princess from the Safavid ruling family in Iran. Often credited to his son 'Azam, it was most certainly commissioned by Aurangzeb himself as part of his imperial ambitions [2]. There is good reason to believe that the commission took place just before the fraternal succession battles for the Mughal throne had begun, that is in the year of her death, 1657 [2]. As per an in situ inscription, the Bibi-ka-Maqbara was completed in 1660/61 after Aurangzeb had become the emperor. Yet, the story of his son being the patron is commonly perpetuated because the commission does not fit the narrative of Aurangzeb's puritanical zeal and austerity. In keeping with that latter image, Aurangzeb's grave at Khuldabad is a very simple affair, a piece of land open to the ground in the corner of a courtyard in the dargah of Sayyad Zain-al-din Shirazi. His own orders regarding his simple burial are quite well known [3]. Even the marble screens added around the spartan grave were only added in the early twentieth century upon the insistence of Lord Curzon, who asked the Nizam of Hyderabad to commission them.

However, other than these, there are at least two residential sites in which Aurangzeb resided, and the architecture of these two locations is largely unrecorded. Both sites are being heavily modified and in part destroyed, through apathy or intervention, as they lack any legal protected status. This essay is about those two residential locations, built almost half a century apart, and the differences between them that embody the change in Aurangzeb's patronage of architecture during his reign.

\section{HISTORIC BACKGROUND: AURANGABAD CITY AND THE SITE OF ALAMGIR}

The city of Khadki (or Khidki) was founded by Malik Ambar (d. 1626) in the early seventeenth century, a period when most of the larger fort-settlements were consciously depopulated in favour of new cities 
founded nearby. Just like Hyderabad (1591) or Nauraspur (1599), the city of Khadki was founded around 1610 at a short distance of about $15 \mathrm{~km}$. Southeast of the Nizam Shahi capital of Daulatabad under Malik Ambar, after their erstwhile capital at Ahmadnagar had been captured by the Mughals in 1600. Malik Ambar's son renamed it Fatehnagar after his father's death, but the name never caught on, and the city was finally captured by the Mughals in 1633 .

The Mughal prince Aurangzeb (1618-1707) was sent to the Deccan as the Viceroy in 1636 . He was transferred to Gujarat in 1645 , and fell out of favor with his father, the Mughal Emperor Shah Jahan. In 1652, he was again appointed as Governor of the Deccan by the emperor, presumably to keep his ambitions of kingship at a conveniently far distance from the court at Agra or Delhi. It was in this second stint in the Deccan, that he made this city his capital. [4] He named the city Aurangabad, but it also came to be well-known by its sobriquet of Khujistah Buniyad, a name that regularly appears on coins and in documents. It is also stated that he called the city Aurangabad, but since that name never appears in any primary sources in his lifetime, it would be safe to assume that it was named in his honor later. It is suggested that the name Khujistah Buniyad was a result of the prosperity of the city and its profusion of mosques, markets, shrines and mansions [5]. It is evident, not only through his political maneuvering, but also through his ambitious building campaigns, that Aurangzeb harbored imperial designs. He had almost scored victories in the two remaining Deccan sultanates, Bijapur and Golconda, when his brother Dara Shikoh manipulated the Mughal emperor Shah Jahan to press for negotiations instead. This was the beginning of a power struggle for succession to the Mughal throne that would eventually be played out between Dara Shikoh and Aurangzeb. Aurangzeb had just commissioned the Bibi-ka-Maqbara, a mausoleum for his wife Rabi'a Durrani (d. 1657), when Shah Jahan was taken ill. Aurangzeb was forced to leave for Delhi in order to press his claims to be the next Mughal emperor. It is noteworthy that the architect for this commission was 'Ata-allah Rashidi (son of Ustad Ahmad Lahori, who was the designer of Shahjahanabad and the Taj Mahal for emperor Shah Jahan). 'Ata-allah and his brother Lutf-allah were also patronized by Dara Shikoh, and patronizing 'Ata-allah to build a monumental Mughal tomb was a cultural coup for Aurangzeb in his claims to being the next emperor. Because Aurangzeb had to rush north, his son 'Azam Shah is credited with overseeing the project. Aurangzeb left Khujista Buniyad in 1657 to claim the Mughal throne, and would return to the Deccan only much later in his conquests against the Deccan kingdoms. The city functioned as an quasiimperial capital of the Mughal empire after the emperor Aurangzeb was more or less permanently resident in the Deccan, from 1683 to 1707 , though he was often either in one of his encampments or on the march.

Aurangzeb had a wall built around the city in 1682 to protect it against raids by the Marathas, and later in 1696 erected a wall around the suburb of Begampura, where the Bibi-ka-Maqbara is located [4]. In 1683, Aurangzeb moved to the Deccan, setting up base in
Aurangabad [6], to subdue the old kingdoms of Bijapur and Golconda, and the new kingdom of Marathas founded under Shivaji Bhonsale (1627-1680) [6]. With this imperial presence, the city quickly expanded, incorporating within it the older city of Malik Ambar. Suburbs and gardens were laid out in its surrounds, and it became an important locus of trade and politics. Along with a large number of other cities that were de facto imperial capitals whenever the presence of the Emperor and administration were located there, Khujista Buniyad became one of the most important cities in the Mughal empire. Burhanpur is another such example of a transient capital. In Aurangabad, Aurangzeb lived in the palace which he had built when he was Governor of the region. The site is called Qila' Ark, and it sits north of the old city on a ridge.

From sometime around 1686, Aurangzeb often camped with his court to a site (called Alamgir now, but probably only posthumously eponymous with Aurangzeb's name), just outside Ahmadnagar near the village of Bhingar. It was probably from this base that he conquered Bijapur in the 1687 , Golconda in 1687, and captured and executed Sambhaji (1657-89), the son of Shivaji, in 1689. But the Maratha kingdom neither acceded nor surrendered, and Aurangzeb spent the remainder of his years in the Deccan, based largely in this campsite, trying to gain complete domination over the Maratha state. Aurangzeb was personally engaged in military campaigns, and moved with the large Mughal imperial camps in the region. However, his semipermanent campsite at Alamgir is unusual, in that it is an imperial military camp where only a few core architectural elements are of a permanent nature. It was around this core that a large tent-city would spring up as the army was in attendance to the emperor. The site is also particularly important because Aurangzeb died here in 1707 and was embalmed at the site before his body was transported to Khuldabad, where he was eventually laid to rest.

The contrast between these two contemporary sites of imperial presence, the palace at Aurangabad and the camp-site at Alamgir, make for a curious comparison. Of very different characters, these two sites of imperial residence present a number of rather curious binaries: a palace in a sub-imperial city in the Mughal domains built in Aurangzeb's early career when he was merely a Viceroy, vis-à-vis a semi-permanent campground on a frontier when he was the Emperor of one of the largest empires of the seventeenth century.

\section{QILA' ARK, AURANGABAD}

Under Aurangzeb, the palace called the Qila' Ark was built on a high point at the northern edge of the old city of Khadki. The old Naukhanda palace, the core of which was built under Malik Ambar, did not become part of this precinct. The expansion of the city, new Mughal fashion, imperial ambition, and a desire for disassociation with Malik Ambar, were all factors towards the construction of a new palace. 


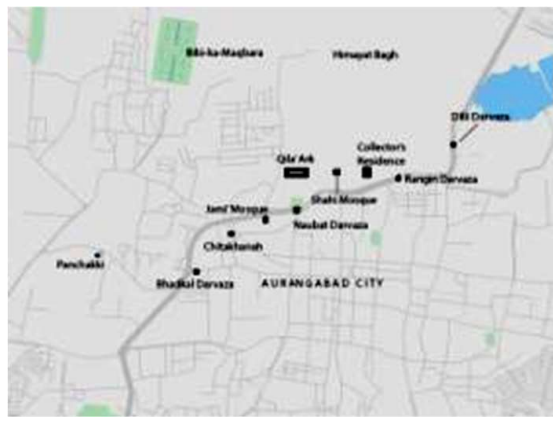

Figure 1. Map of Aurangabad (Source: author, 2014)

The location was just north of the older palace (Qila' Naukhanda, the site of which now occupies the Womens' College of Ahmadnagar) (figure 1). The Qila، Ark campus had a royal mosque, and possibly other buildings, the location of which is difficult to conjecture without archaeological investigation. The palace overlooked the city of Aurangabad to the south, and had a vantage over large gardens and orchards to the north (now known as Himayat Bagh). Built by Aurangzeb when he was the Governor of the Deccan from 1653 to 1658 , it was occupied by his family and court whenever he was in the city. At a short distance in the north-west, the garden suburb of Begumpura dominated by the Bibi-ka-Maqbara was built within a few years, and the palace provided an excellent vantage to see that building.

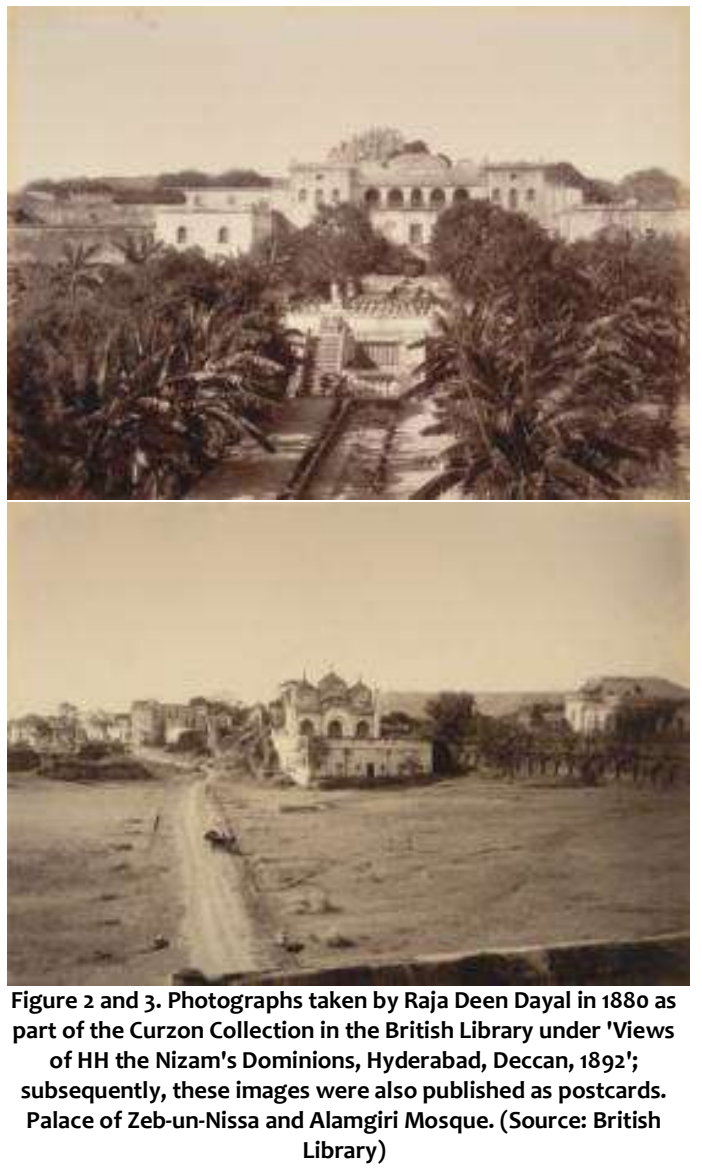

The Qila' Ark today survives in a fragmentary form, and only two structures of note are still extant. Yet, every publication such as the Imperial Gazetteer that describe Aurangabad mention the Qila' Ark, at least in passing [7]. Of the two structures that survive, an actual terraced palace building was reasonably intact till the early twentieth century, but it has been steadily dismantled since it was converted to Milind Arts College. The other building is the royal mosque, now known as the Shahi Mosque, but referred to as 'Alumgeer's [sic] Mosque' or Alamgiri Mosque as late as the early twentieth century. The British Library has several photographs with such labels, taken by Henry Mack Nepean in 1868 and by Lala Deen Dayal in the 1880 s.

Both these structures are clearly identifiable in two photographs taken by Raja Deen Dayal in 1880 (figure 2 and figure 3). Later on, the palace became apocryphally associated with his daughter Zeb-un-Nisa (1638-1702), thus erasing any association of Aurangzeb with the site. The Subahdari, now converted into the District Collector's Residence, was a mansion within the Qila' Ark complex meant for subordinate officials.

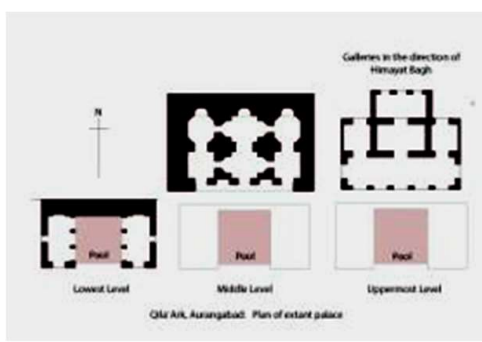

Figure 4. Plan of the upper quarters of the extant palace (Source: author, 2014)

The royal Qila' Ark residence comprised a series of terraces, with the topmost rooms overlooking gardens towards the north, and a series of cascading levels towards the south with a vista of the great maidan (which was built over in 2009). The upper part of this palace is extant, though greatly modified. It is still possible to make out a central chamber with a banglavaulted ceiling, flanked by two smaller rooms which have pyramidal vaults. The throne room or takht, as it has been described in the District Gazetteer, being rostral and of simple description, is set facing the garden (figure 4) [8].

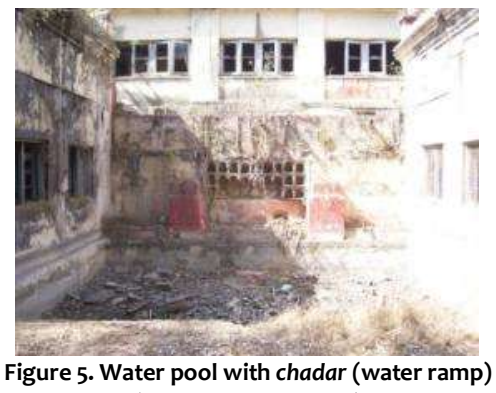

(Source: author, 2014) 
Along the center of these terraces, one can make out the remnants of a water channel, complete with a Mughal chadar - a water ramp (figure 5). In exact alignment along the central axis of these chambers, along the water channel and the (now built-over) maidan is the Naubat Darvaza (figure 6). It is a large portal, and as its name suggests, it would have housed musicians to announce the arrival of important visitors.

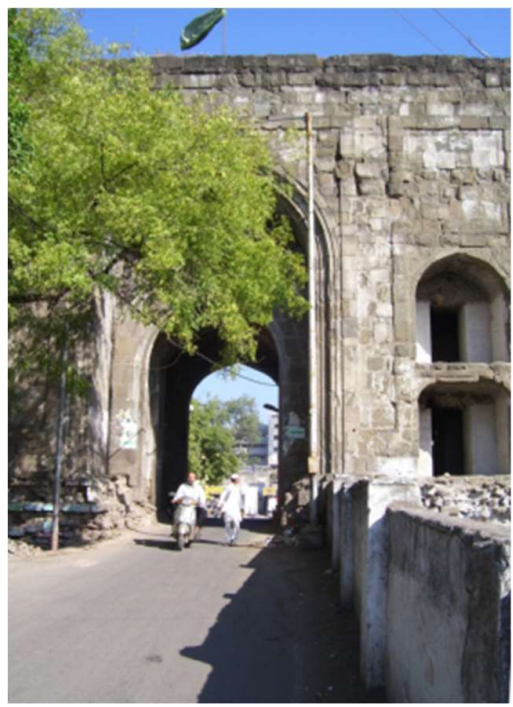

Figure 6. Naubat Darvaza (Source: author, 2014)

Other gates from the citadel complex include the Dilli Darvaza and the Makkai Darvaza, which have been described as the extent of the royal palace [8]. The Makkai Darvaza leads across the Kham river to Begumpura and the Bibi-ka-Maqbara. To the west of this palace area is an open field called the 'Aam Khas Maidan, a name that suggests its function of separating relatively public areas from the private areas of the palace. (The name also resonates with that of a large gateway ('Am Khas Darvaza) that separates the public and private areas of the palace of the Mughal commander of Daulatabad. This latter gateway is now part of the sculpture museum set up in the fort of Daulatabad). The smaller maidan next to the Shahi Mosque has now been walled, and the gate reportedly had an inscription from 1659, making it likely that the mosque was constructed on the site of an earlier mosque [8]. The author was unable to locate the inscription in 2012.

The original commanding position of the upper rooms of the palace, at the summit of a ridge looking out over the city and the gates that lead to it, such as the Naubat Darvaza directly to the south, is now altogether obscured by a new multi-storied concrete structure. Similarly lost is the view to the north, over the large garden-orchard plains which eventually came to be known as Himayat Bagh. Originally an artificial lake, this area was ordered to be filled in soon after its construction around 1656 for reasons of health, and the drained swamp became the site for a large garden. The pre-Mughal water-works at Harsul were to the north of this garden area at a distance of a few kilometers, and supplied water to the city.

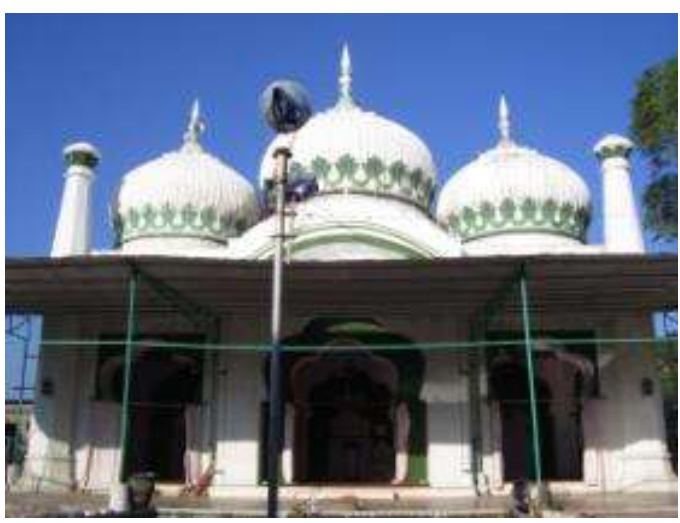

Figure 7. The Shahi Mosque for the Emperor Alamgir.

(Source: author, 2012)

The Shahi Mosque commissioned by Aurangzeb within this complex is similar to the famous Moti Masjid that was built in the Red Fort at Delhi by him, just like the ones at Lahore and Agra built by Shah Jahan. On a similar scale with three bulbous domes, this mosque too was clearly meant to be a private mosque for the Emperor (figure 7).

Several other palaces were also built in Aurangabad under the Mughals, and one of them, built by a Rajput noble called Pahad Singh survives as Soneri Mahal, and currently houses the Maharashtra State Museum for Aurangabad [9]. Gardens were set up in various suburbs of the city, and the Rauza Mahal (currently part of the Dr Rafiq Zakaria College and the Taj Hotel), a fine example of such a quadripartite garden, has been reasonably preserved.

Within the Qila' Ark, it is possible to connect to dots and conjecture a plan of the larger palace complex. Several other elements that survive are useful in this exercise, notably the gateways that are now without any context, and the nomenclature for streets and neighborhoods that form the residual memory of past physical realities.

\section{ALAMGIR NEAR AHMADNAGAR}

This royal enclosure, used as an administrative and military camp by the emperor, whenever he was in Ahmadnagar camping with his armies, has an understated presence. Known today as Alamgir (the eponymous attribution a result of Aurangzeb's presence there), the core of the imperial camp is still extant, under the layers of accretions that have been added over the past few decades, as the site has become a large residential school for the Madrasa Darul-Uloom.

At a distance of only a few kilometers to the east of the city of Ahmadnagar, close to the village of Bhingar, the site of Alamgir comprises a precinct complete with an enclosure wall (figure 8), a mosque, and a baradari (pavilion) (figure 9). 


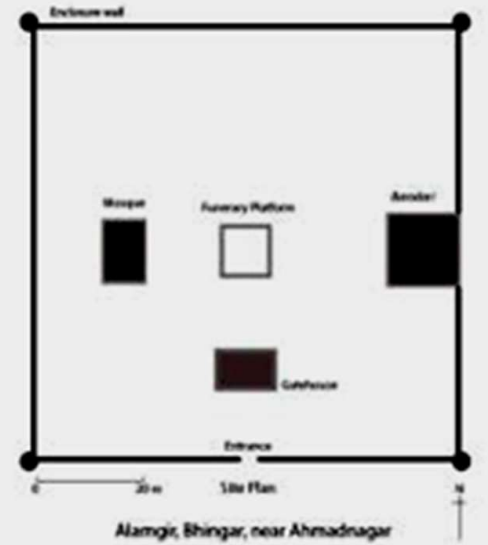

Figure 8. Plan of site of Alamgir with a mosque, a baradari (pavilion) and an enclosure wall. (Source: author, 2014)

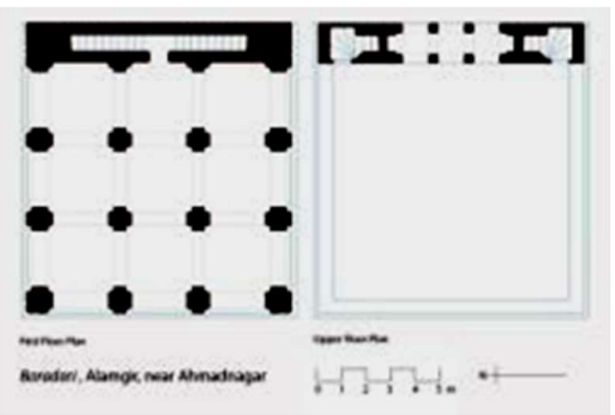

Figure 9. Plan of the baradari at Alamgir. (Source: author, 2014)

It also would have housed imperial tents and though it looks spartan now (partly a result of new construction and the lack of furnishings), it would have been quite impressive despite its modest scale. The enclosure walls are approximately $80 \mathrm{~m}$ on every side, and the compound is entered through a gateway on the south.

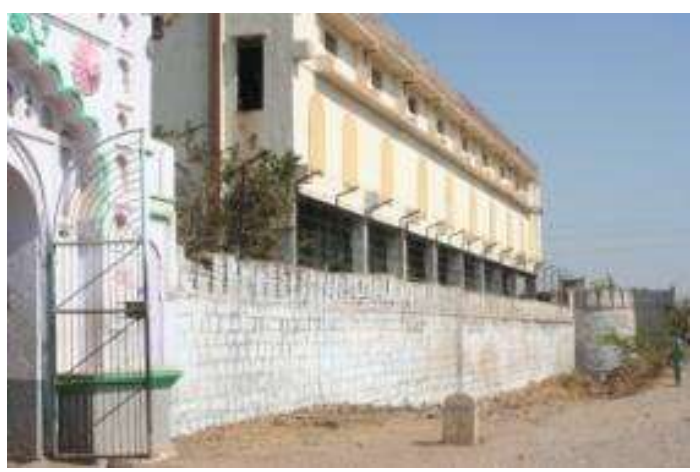

Figure 10. The enclosure wall is crenellated with merlons with a rounded bastion at every corner of the square area that it encloses. (Source: author, 2014)

The enclosure wall is crenellated with merlons and is about $4 \mathrm{~m}$ high, with a rounded bastion at every corner of the square area that it encloses (figure 10).

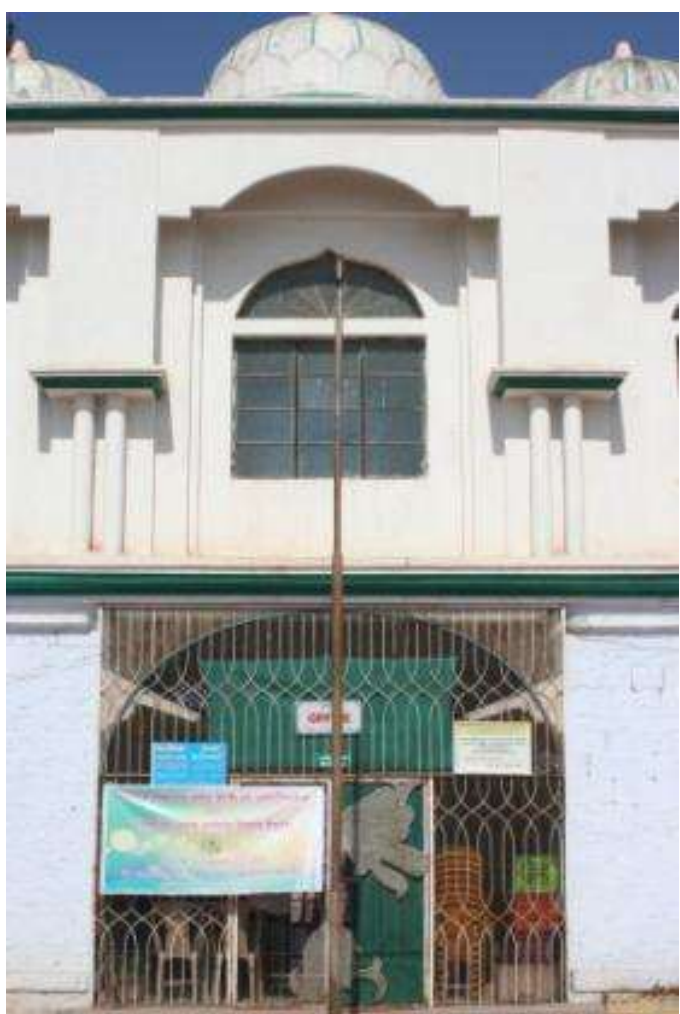

Figure 11. Gatehouse, with a few gallery chambers for guards. (Source: author, 2014)

Immediately inside the gateway is a building that can be best described as a gatehouse, with a few gallery chambers for guards (figure 11). The gatehouse has had a second story added in the early 2000 s.

Inside the enclosure walls is the mosque, the core of which appears to be Nizam Shahi, with extensions on both sides. The mosque is aligned with the centre of the western wall, and is slightly off-center, to the west on the north-south axis. The mosque has recently been enlarged with a reinforced concrete construction.

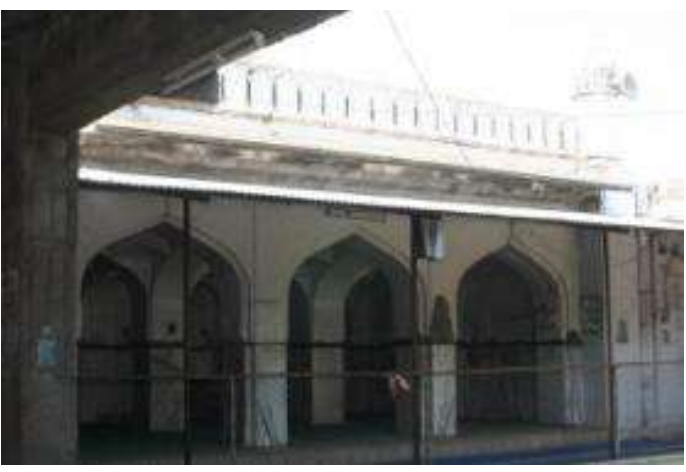

Figure 12. Mosque at Alamgir. (Source: author, 2014)

The center of the eastern enclosure wall is taken up by one side of a baradari of nine bays (figure 12). The building is a single story tall, but the rear of the building, which is flush with the compound wall does not have any openings on the first floor, instead having a triplebayed pavilion on the roof (figure 13). 


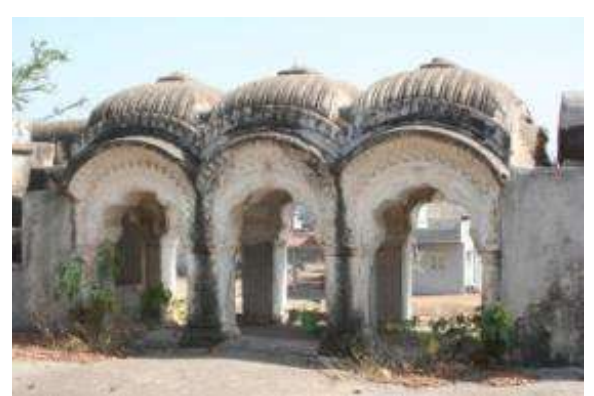

Figure 13. The triple-bayed pavilion on the roof of the baradari. (Source: author, 2014)

This roof pavilion has arched openings on all sides, and is capped by three domes. From outside the enclosure, it appears to have served the purpose of a jharoka from where the emperor would have given darśana to his select troops outside (figure 14). As described by R. Nath, "But jharoka-darshana was so integrally institutionalized within the Mughal Kingship and State, and had become so necessary a function of the Mughal Emperor that he could not avoid it" [10].

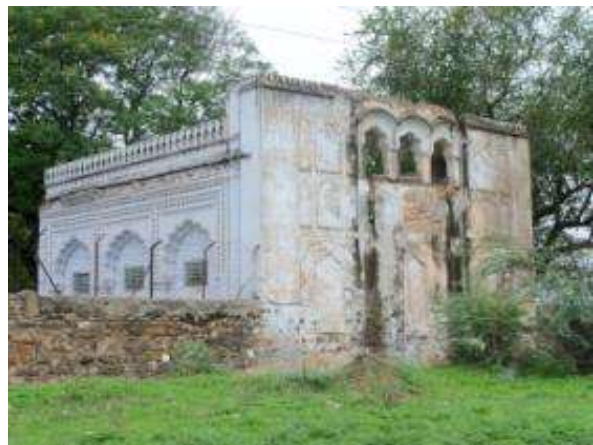

Figure 14. The baradari with a jharoka from outside the enclosure wall. (Source: author, 2014)

We know of this important rite started by Akbar was practiced around an appearance in a window or balcony that faced east [11]. This ritual was important for several reasons, one of which was to provide an assurance to the soldiers that the emperor was alive and well, thus keeping rumors at bay. As explained by Jos Gommans, "Especially at the times the Mughal camp was isolated from the outside world, it appears that the incessant rumours about the emperor's demise tended to stimulate negotiations..."[12].

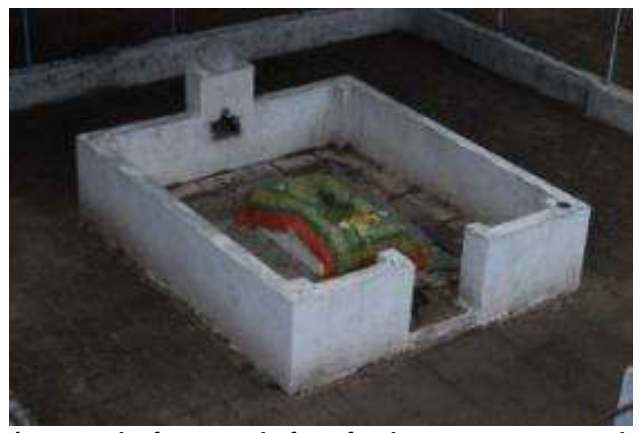

Figure 15. The funerary platform for the emperor Aurangzeb. (Source: author, 2014)
Exactly in the center of the enclosure is a platform with a pit, where the body of Aurangzeb was kept till it was prepared for its final destination at Khuldabad (figure 15). This platform is about $10 \mathrm{~m}$ on each side, and about $1 \mathrm{~m}$ high. It not only marks the center of the royal space, but is also at the intersection of the central axes of the gatehouse, the baradari, and the mosque, marking the administrative, religious, and ceremonial presence of the emperor respectively. It was probably built in haste, since it is very modest in scale, and relatively undecorated as compared to the large palace sites of the Mughals.

\section{CONCLUSION}

Stylistically, Aurangzeb's reign was not marked by any evolution in architecture, stylistically or structurally. The Mughal architectural style was already a fully developed tradition, and was being used across most of the sub-continent as the eminent language of courtly power by the late seventeenth century [19]. Aurangzeb's reign was the last flourish of building activity by the Mughal dynasty, and the fragmentation of the empire began soon after his death. Most of the emergent parvenu local kings who filled in the power vacuum imitated the Mughals, as it was the only architecture of court culture and power that they had known.

Mughal emperors from Akbar to Aurangzeb all commissioned mosques, mausolea, and palaces as part of their imperial architectural language. Aurangzeb was different from the earlier Mughal emperors, but not on account of any change in architectural program or style; his reign was uniquely marked by a decline in scale and ornament, as he retreated into frugality towards the end of his life. This period was ironically marked by a larger economy and a greater territory for the Mughal state, but the state had begun devolving power, and maybe because of his Pyrrhic victories in the Deccan, Aurangzeb himself had become austere. Apart from financial pressures caused by his pyrrhic victories in the Deccan, Aurangzeb as emperor was also known to have become a scrimping patron of the arts upon becoming emperor. The greatest paintings and architectural creations at his court were all very early in his career. For example, after an initial show of interest in the royal painting atelier, he ignored it, and many of the artists migrated to other courts [13]. Similarly, the last thirty years of his reign are not marked by any great architectural commissions other than mosque expansions at Bijapur and Golconda. Whether it was the incessant military campaigning in temporary camps, a depleted treasury, a shift in attitude and personality, or a combination of all these factors, the end result was that royal residences never achieved the same grandeur as earlier Mughal palaces. Aurangzeb had been in the same area for over two decades, and reasons of temporary encampments alone cannot explain the shift in attitude. These two Mughal residences in the Deccan are exemplary of the change in his architectural patronage over time, and they appear at the beginning and the end of his role as the grand imperial patron, marking half a century between them. 


\section{References}

[1] J. Bloom and S. Blair, The Grove Dictionary of Islamic Art and Architecture. Oxford: Oxford University press, 2009.

[2] L. E. Parodi, "The Bibi-ka Maqbara in Aurangabad: A Landmark of Mughal Power in the Deccan?," East West, vol. 48, no. 3/4, pp. 349-383, 1998.

[3] J. Sarkar, Anecdotes of Aurangzib (English translation of Ahkam-i Alamgiri ascribed to Hamid-ud-din Khan Bahadur). Calcutta: M.C. Sarkar and Sons, 1925.

[4] Maharashtra State Gazetteer: Aurangabad District (Revised edition). Bombay: Government of Maharashtra, Gazetteers Department.

[5] N. Green, "Auspicious Foundations: The Patronage of Sufi Institutions in the Late Mughal and Early Asaf Jah Deccan," South Asian Stud., vol. 20, no. 1, pp. 71-98, 2004.

[6] District Gazetteer of Aurangabad. Bombay: Published under the orders of His Highness the Nizam's Government, printed at The Times of India Steam Press, 1884.
[7] Imperial Gazetteer of India, Provincial Series, Hyderabad State. Calcutta: Superintendent of Government Printing, 1909.

[8] Gazetteer of the Nlzam's Dominions?] Aurangabad District. Mumbai: Government Central Press, 2006.

[9] G. Michell, "Daulatabad and Khuldabad under the Mughals (1660-1707)," in Silent Splendour: Palaces of the Deccan (14th - 19th century), Helen Phil., Mumbai: Marg Publications, 2010, pp. 34-43.

[10] R. Nath, “A curious inscription of Shah Jehan's Jharokhā, Shah Burj, Red Fort, Delhi (1639-48 AD)," Indica, Heras Inst. Indian Hist. Cult., vol. 40, no. 2, pp. 153-162, 2003.

[11] A. Eraly, The Mughal World: Life in India's Last Golden Age. New York: Penguin Books, 2007.

[12] J. Gommans, Mughal Warfare: Indian Frontiers and Highroads to Empire 1500-1700. New York: Routledge, 2002.

[13] S. Kossak, Indian Court Painting, 16th-19th Century. New York: Metropolitan Museum of Art, 1997. 